\title{
Formula and Quality Study of Multigrain Noodles
}

\author{
QI Jing, LYU Yingguo*, WANG Yuanhui, CHEN Jie, HOU Panfeng
}

College of Food Science and Technology, Henan University of Technology, Zhengzhou 450001, China

Abstract: Multigrain noodles were made by corn and wheat flour as the main ingredients and with small ratios of oat flour, soybean flour and millet flour through extrusion process. Simplex centroid design was used to analyze gelatinization characteristics of the mixed flour, rheological characteristics of the doughs, cooking qualities and sensory qualities of noodles. A proper formula for multigrain noodles obtained as outcome: $45 \%$ corn flour, $40 \%$ wheat flour, $4 \%$ oat flour, $11 \%$ millet flour. Compared to the wheat noodles, the multigrain noodles had higher content in fat, dietary fiber and total resistant starch, but it did content less proteins than wheat noodles.

Keywords: Multigrain noodles; Extrusion process; Simplex centroid design

\section{Introduction}

For noodles, a traditional food in most eastern countries, are usually made by wheat flour and have been widely consumed by ancient people. But recent increasing demand in multigrain food market is due to an increased awareness of reducing disease risks and managing chronic diseases by intaking health-promoting food $^{[1-2]}$. Some scholars reported that consuming multigrain food was associated with the decreasing risks in cardiovascular diseases and metabolic risk factors ${ }^{[3-4]}$. Proper multigrain combinations could satisfy human body's need with appropriate and reasonable nutritional contents. Also, it could provide a better pattern of amino acids intake if beans be involved in the formula ${ }^{[5]}$.

Corn has the largest yield in the world every year, it has more significant antioxygenation than most other grains. That is because corn has much higher content of phenolics, ferulic acid, and flavonoid ${ }^{[6-7]}$. Beghin et al. ${ }^{[8]}$ did a biological value test for corn-soy-wheat noodles, the results indicated that corn-soy-wheat noodles had a positive effect on nutritional recuperation for Brazilian malnourished children. Liao et al. ${ }^{[9]}$ reported that oat noodles could significantly decrease the lipid profile as well as blood pressure in both normal and mild hypercholesterolemic subjects by partially replacement of staple food in breakfast. Using of multigrain gluten-free sourdoughs could prolong shelf-life of the product by decreasing staling rate, which were caused by the impact of pasting properties ${ }^{[10]}$. Used multigrain blend replacing whole-wheat flour to yield a more nutritious Indian flat bread also with good physical and sensory characteristics ${ }^{[11]}$.

The goal of this study was to develop a kind of multigrain noodles that could be accepted for general consumers and also to analyze its nutritional qualities. As multigrain noodles were lack of wheat gluten, it cannot be processed by traditional sheet-cutting way. In this study, multigrain noodles were made with corn and wheat flour as the main ingredients and small variable

Received: 5 September 2018 /Accepted: 14 December 2018

Supported by National Natural Science Foundation of China (31401642).

*Corresponding author. E-mail: 583661631@qq.com

CHenan University of Technology 2018

QI J, LYU Y G, WANG Y H, et al. Formula and Quality Study of Multigrain

Noodles[J]. Grain \& Oil Science and Technology, 2018, 1(4): 157-162. ratios of oat flour, soybean flour and millet flour by extrusion process. And gelatinization characteristics of the mixed flour, rheological characteristics of the doughs, cooking qualities and sensory qualities of noodles were studied respectively.

\section{Materials and Methods}

\subsection{Materials}

Wheat flour (tailored flour) was obtained from Wilmar International Limited (13.10\% moisture content, $11.65 \%$ protein content on dry matter basis); Corn (13.23\% moisture content, $3.6 \%$ protein content on dry matter basis), oat (11.72\% moisture content, $14.56 \%$ protein content on dry matter basis), soybean ( $7.91 \%$ moisture content, $32.03 \%$ protein content on dry matter basis) and millet (10.40\% moisture content, $9.28 \%$ protein content on dry matter basis) purchased from countryside of Zhengzhou City, Henan Province, China, and the flour were milled by fine pulverizer and filtered by a 60 mesh sieve.

\subsection{Mixtures Design}

Simplex centroid design was used to pick up a best multigrain formula. And all the data was analyzed by Design-Expert 8.0.6.1. Basic components were determined by the pre-experiment: $50 \%$ water addition, $45 \%$ corn flour, $40 \%$ wheat flour, and $15 \%$ multigrain flour. In addition, it's best to keep oat addition between $4 \%$ and $15 \%$. The formula design is showed in Table 1.

Table 1 Simplex centroid design that is applied for the optimization of multigrain noodles

\begin{tabular}{crcr}
\hline \multirow{2}{*}{ Mixtures } & \multicolumn{3}{c}{ Ingredients $(\mathrm{g} / 100 \mathrm{~g}$, dry basis $)$} \\
\cline { 2 - 4 } & Oat & Soybean & Millet \\
\hline O1 & 4.00 & 5.50 & 5.50 \\
O2 & 5.83 & 1.83 & 7.33 \\
O3 & 5.83 & 7.33 & 1.83 \\
O4 & 15.00 & 0.00 & 0.00 \\
O5 & 4.00 & 11.00 & 0.00 \\
O6 & 9.50 & 5.50 & 0.00 \\
O7 & 7.67 & 3.67 & 3.67 \\
O8 & 4.00 & 0.00 & 11.00 \\
O9 & 9.50 & 0.00 & 5.50 \\
O10 & 11.33 & 1.83 & 1.83 \\
\hline
\end{tabular}




\subsection{Preparation of Noodles}

Multigrain flour (200 g) was mixed with distilled water $(100 \mathrm{~g})$ in a dough mixer for $5 \mathrm{~min}$. After mixing, the obtained doughs were allowed to rest in a plastic bag and kept at room temperature for $20 \mathrm{~min}$. After resting, put doughs on a wire rack in steamer, for 20 min steaming. The doughs were extruded by a noodle extruder, then the head and the end of the noodles were cut off and steamed for $20 \mathrm{~min}$.

Wheat flour noodles were prepared with $100 \mathrm{~g}$ wheat flour, $32 \mathrm{~g}$ distilled water and $1 \mathrm{~g}$ salt. Salts were dissolved in water prior to addition with wheat flour. Ingredients were mixed using a mixer for $15 \mathrm{~min}$. The obtained dough was placed in a plastic bag and kept at room temperature for $15 \mathrm{~min}$. Then the dough was passed through several rollers with an initial gap setting at width $2.2 \mathrm{~mm}$, and final gap setting at width $1.1 \mathrm{~mm}$. The sheet was cut into $2.0 \mathrm{~mm}$ wide noodles by the cutter roller. The dimensions of the resultant noodle strands were $2.0 \mathrm{~mm}$ in width and $1.1 \mathrm{~mm}$ in thickness.

\subsection{Pasting Properties of Multigrain Flour}

Pasting properties of multigrain flour were determined by Rapid Viscosity Analyzer (RVA-4, Newport Scientific, Australia) according to the AACC Method 76-21 ${ }^{[12]}$.

\subsection{Doughs Rheological Properties}

The doughs rheological properties of multigrain noodles were determined by a controlled stress rheometer (Thermo Scientific HAAKE MARS 60, Thermo Fisher) according to Marcoa et al. ${ }^{[13]}$ The sample doughs were rest for $30 \mathrm{~min}$ in valve bags, then placed between the plates ( $1 \mathrm{~mm}$ gap). After turning down the rotor and then cut the excess doughs and coated with vegetable oil in order to prevent evaporation during the measurements. After $5 \mathrm{~min}$ relaxation, the tests were performed at $30{ }^{\circ} \mathrm{C}, 50 \%$ of stress. Frequency sweep tests were performed from 0.01 to $10 \mathrm{~Hz}$.

\subsection{Cooking Properties of Multigrain Noodles}

\subsubsection{Optimum Cooking Time (OCT)}

Noodles samples were cooked in boiled water with $2 \%$ salt (20 strips $/ 800 \mathrm{~mL}$ ), the optimum cooking time was defined as the white core in noodles disappeared when compressed between two glass plates.

\subsubsection{Cooking Loss (CL)}

Cooking loss was the weight of the residues. It can get by drying the cooking water in an oven at $105^{\circ} \mathrm{C}^{[14]}$.

\subsubsection{Water Absorption (WA)}

Water absorption was determined by weighing noodles before and after cooking ${ }^{[14]}$.

\subsubsection{Sensory Evaluation of Multigrain Noodles}

Noodles samples were cooked to their optimum cooking time and presented randomly in different plates. The sensory evaluations were performed with a panel of 10 experts according to sensory evaluation standards in Table 2 .

\subsection{Nutritional Component Analysis}

Noodle samples were cooked to their optimum cooking time, then they were freeze-dried and milled for test. Protein concentration was analyzed according to the AACC Method 46-11 $\mathrm{A}^{[15]}$. Using Soxhlet extractor method for testing fat content and method $985.29^{[16]}$ for dietary fiber (DF). Total starch (TS) were hydrolyzed by the method of GB/T $5009.9-2008^{[17]}$ and analyzed by dinitro salicylic acid (DNS) method ${ }^{[18]}$ to calculate the content of TS. Resistant starch (RS) were treated according to the AOAC Method 2002.02 ${ }^{[19]}$ and DNS method to calculate the content of RS.

Table 2 Sensory evaluation standards for multigrain noodles

\begin{tabular}{|c|c|c|}
\hline & Full score & Grading \\
\hline Color & 10 & $\begin{array}{l}\text { The color and brightness of samples, yellow and bright for } 8.5-10 \text { points, normal brightness for 6-8.4 points, } \\
\text { dark color and no brightness for } 1-6 \text { points. }\end{array}$ \\
\hline Surface condition & 10 & $\begin{array}{l}\text { The smooth of surface and degree of swelling, dense and smooth surface structure for } 8.5-10 \text { points, slightly } \\
\text { rough swollen and deformed surface for } 6-8.4 \text { points, rough swollen and severely deformed surface for } \\
1-6 \text { points. }\end{array}$ \\
\hline Mouthfeel & 20 & $\begin{array}{l}\text { The amount of force required to cause the sample to disintegrate (between the molars), moderate intensity } \\
\text { for } 17-20 \text { points, slightly hard or soft for } 12-17 \text { points, too hard or too soft for } 1-12 \text { points. }\end{array}$ \\
\hline Chewiness & 25 & $\begin{array}{l}\text { The chewy and elastic of a sample during the chew. Strong chewy and elastic for } 21-25 \text { points, slightly } \\
\text { chewy and elastic for } 15-21 \text { points, not elastic enough for } 10-15 \text { points. }\end{array}$ \\
\hline Springiness & 25 & $\begin{array}{l}\text { The ability of a sample to regain its shape after the first bite between the molars. Refreshing and non-stick } \\
\text { teeth } 21-25 \text { points, refreshing and slightly sticky teeth } 15-1 \text { points, unpleasant mouthfeel and sticky } \\
10-15 \text { points. }\end{array}$ \\
\hline Slipperiness & 5 & $\begin{array}{l}\text { The smooth mouthfeel of a sample during tasting, smooth for } 4.3-5 \text { points, slightly smooth for } 3-4.3 \text { points, } \\
\text { not smooth for } 1-3 \text { points. }\end{array}$ \\
\hline Flavor & 5 & $\begin{array}{l}\text { The flavor of a sample during tasting, have the multigrain's flavor for } 4.3-5 \text { points, basically no smell for } \\
3-4.3 \text { points, smelly for } 1-3 \text { points. }\end{array}$ \\
\hline
\end{tabular}

\subsection{Statistical Analysis}

All experimental data were presented as the mean \pm standard error of the mean (SEM) of at least three independent replicates. Any two data were considered statically significant at $P<0.05$ and verified by one-way analysis of variance (ANOVA) using SPSS statistical software (23.0, SPSS Inc, Chicago, IL, USA).

\section{Results and Discussion}

\subsection{The Gelatinization Characteristics of Different Formula Flour}

During the heating process, starch particles absorbed water to extend their volumes and fell apart to pieces, then starch molecules over brim and combined with residues to form 
a three-dimensional network. Extrusion was a production process which applied by high temperature with short time; during this process, starches were gelatinized, proteins were denatured, and extrudates were restructured on the texture and histology ${ }^{[20]}$. When starch particles extended to their maximum volumes, they reached the peak of the gelatinization viscosity and the particles would totally fall apart with the decreasing of gelatinization viscosity ${ }^{[1]}$. The viscosity produced by starch gelatinization directly affected the property of noodle doughs. The gelatinization properties of flour could be used to assess the applicability in noodles making ${ }^{[21]}$. Unlike traditional wheat noodles, the gluten proteins in wheat noodles could form a three-dimensional gluten network as structure; multigrain noodles did not have enough gluten protein, the viscosity provided by pasting was to replace the gluten network to combine starch, proteins and other objects in noodles. To value the applicability of noodles which were made from different content of multigrain flour, this experiment studied gelatinization properties of every designed formula. Results were shown in Table 3. A modeling diagram was built as Fig. 1 in viscosity properties, such as the peak, bottom and final figure of the properties. In Fig. 1, oat flour improved viscosity of the mixture, but the addition of soybean inversed. For more details, it could be seen in Table 3, mixture O4 (15\% oat flour) had highest viscosity. The reason was that oat contented enough $\beta$-glucan and good property of swelling, its solution with water had high viscosity. And during gelatinization, starch molecules swelled to push every single starch together and enhanced the force of friction; therefore, to increase the gelatinization viscosity ${ }^{[22]}$. Soybean flour caused the decrease of viscosity because it had lower starch content, but in RVA heating and cooling process, starch gelatinization was the main reason that caused increasing viscosity $^{[23]}$. Millet starch did not have good stability ${ }^{[24]}$; thus, it would affect trough values of the mixture flour.

Table 3 Viscosity property of different mixtures

\begin{tabular}{|c|c|c|c|c|c|c|c|}
\hline Sample & Peak viscosity & Trough & Breakdown & Final viscosity & Setback & Peak time (min) & Pasting temperature $\left({ }^{\circ} \mathrm{C}\right)$ \\
\hline $\mathrm{O} 1$ & $1813.33 \pm 28.20^{\mathrm{f}}$ & $1181.33 \pm 21.71^{\mathrm{e}}$ & $632.00 \pm 6.66^{\mathrm{ef}}$ & $3318.67 \pm 18.11^{\mathrm{g}}$ & $2137.33 \pm 13.78^{d}$ & $5.76 \pm 0.02^{\mathrm{cd}}$ & $78.23 \pm 0.03^{\mathrm{a}}$ \\
\hline $\mathrm{O} 2$ & $2088.67 \pm 5.78^{\mathrm{c}}$ & $1389.67 \pm 26.39^{\mathrm{c}}$ & $699.00 \pm 27.06^{\mathrm{abc}}$ & $3538.00 \pm 4.58^{\mathrm{e}}$ & $2148.33 \pm 21.85^{\mathrm{d}}$ & $5.92 \pm 0.04^{\mathrm{ab}}$ & $73.38 \pm 4.07^{\mathrm{abc}}$ \\
\hline $\mathrm{O} 3$ & $1768.33 \pm 18.02^{\mathrm{f}}$ & $1165.33 \pm 25.37^{\mathrm{e}}$ & $603.00 \pm 11.79^{f}$ & $3470.67 \pm 4.33^{\mathrm{f}}$ & $2305.33 \pm 21.96^{\mathrm{c}}$ & $5.70 \pm 0.02^{\mathrm{d}}$ & $67.92 \pm 4.72^{b c}$ \\
\hline $\mathrm{O} 4$ & $2252.67 \pm 18.55^{\mathrm{a}}$ & $1570.67 \pm 12.39^{a}$ & $682.00 \pm 24.11^{\mathrm{bcd}}$ & $4040.33 \pm 36.09^{a}$ & $2469.67 \pm 39.50^{\mathrm{ab}}$ & $6.03 \pm 0.06^{\mathrm{a}}$ & $69.07 \pm 3.19^{\mathrm{abc}}$ \\
\hline O5 & $1572.00 \pm 7.23^{\mathrm{g}}$ & $1055.00 \pm 8.08^{\mathrm{f}}$ & $517.00 \pm 2.52^{\mathrm{g}}$ & $3291.67 \pm 39.83^{g}$ & $2236.67 \pm 36.76^{\mathrm{c}}$ & $5.72 \pm 0.08^{d}$ & $71.52 \pm 2.98^{\mathrm{abc}}$ \\
\hline O6 & $1935.33 \pm 10.33^{\mathrm{e}}$ & $1296.33 \pm 19.70^{\mathrm{d}}$ & $639.00 \pm 9.54^{\mathrm{def}}$ & $3822.67 \pm 17.36^{\mathrm{c}}$ & $2526.33 \pm 5.81^{\mathrm{a}}$ & $5.76 \pm 0.02^{\mathrm{cd}}$ & $72.88 \pm 2.27^{\mathrm{abc}}$ \\
\hline $\mathrm{O} 7$ & $2029.67 \pm 22.24^{\mathrm{d}}$ & $1360.67 \pm 34.28^{\mathrm{c}}$ & $669.00 \pm 16.29^{\mathrm{cde}}$ & $3621.00 \pm 22.30^{\mathrm{d}}$ & $2260.33 \pm 12.99^{c}$ & $5.89 \pm 0.06^{\mathrm{bc}}$ & $64.68 \pm 1.22^{\mathrm{c}}$ \\
\hline $\mathrm{O} 8$ & $2112.00 \pm 7.51^{\mathrm{c}}$ & $1376.67 \pm 15.51^{\mathrm{c}}$ & $735.33 \pm 8.09^{\mathrm{a}}$ & $3438.00 \pm 13.00^{\mathrm{f}}$ & $2061.33 \pm 19.10^{\mathrm{e}}$ & $5.76 \pm 0.02^{\mathrm{cd}}$ & $76.32 \pm 0.28^{\mathrm{ab}}$ \\
\hline O9 & $2239.67 \pm 8.82^{\mathrm{ab}}$ & $1524.33 \pm 16.83^{\mathrm{ab}}$ & $715.33 \pm 8.74^{\mathrm{ab}}$ & $3830.67 \pm 12.55^{\mathrm{c}}$ & $2306.33 \pm 12.12^{\mathrm{c}}$ & $5.98 \pm 0.00^{\mathrm{ab}}$ & $73.12 \pm 4.41^{\mathrm{abc}}$ \\
\hline $\mathrm{O} 10$ & $2194.00 \pm 21.93^{b}$ & $1501.00 \pm 24.21^{\mathrm{b}}$ & $693.00 \pm 4.73^{\mathrm{abc}}$ & $3949.67 \pm 18.50^{b}$ & $2448.67 \pm 23.84^{b}$ & $5.92 \pm 0.04^{\mathrm{ab}}$ & $76.83 \pm 0.69^{\mathrm{ab}}$ \\
\hline
\end{tabular}

Note: Different letters in each column show statistically significant differences $(P<0.05)$ in different mixtures.

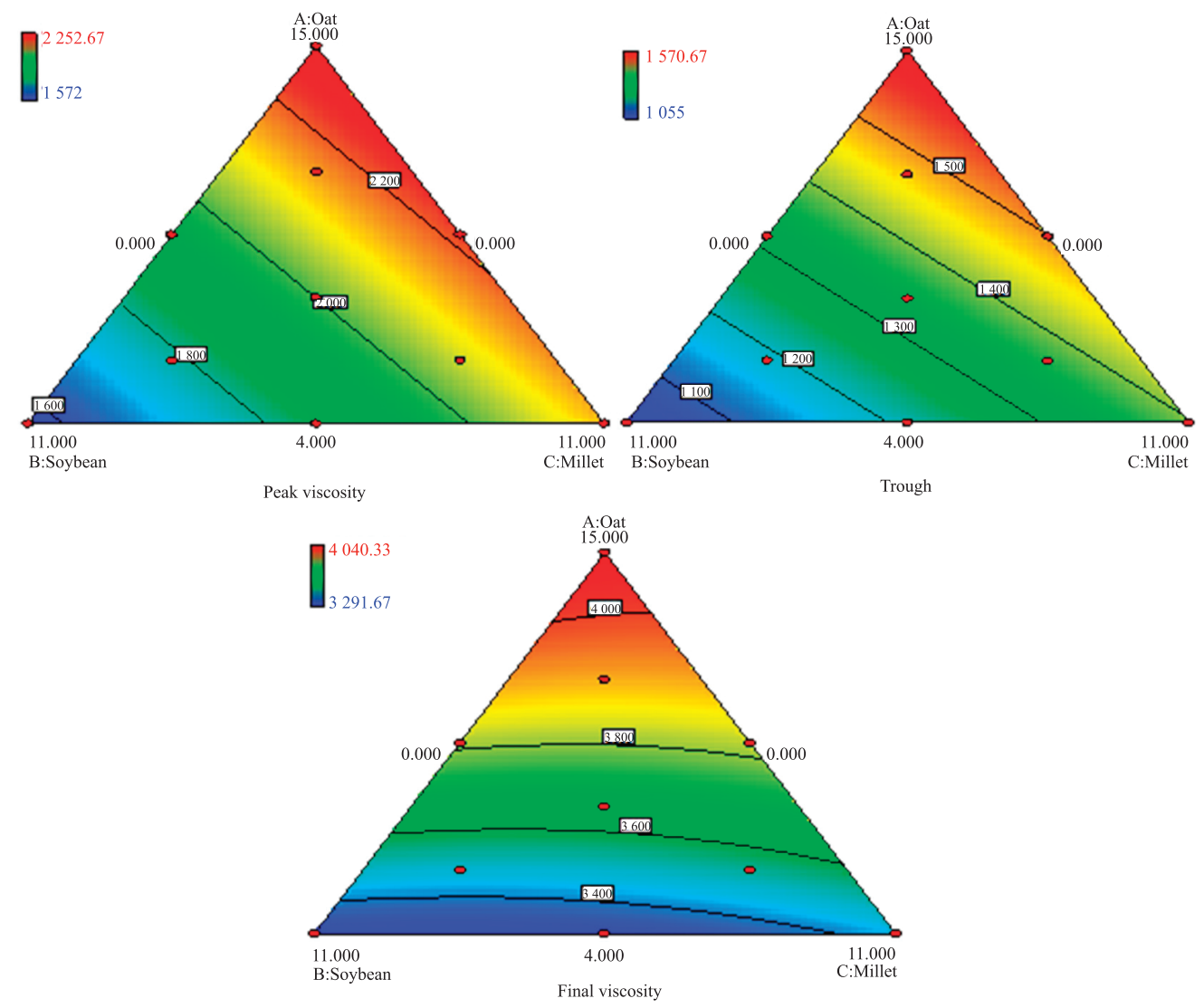

Fig. 1 Model graph of viscosity property of different mixtures 


\subsection{The Rheological Characteristics of Noodle Doughs Made from Different Formula Flour}

Rheological characteristics were related to processing abilities, processing conditions and the qualities of the final products, which were important in food making ${ }^{[25]}$. Fig. 2 showed the changes in dynamic and viscoelastic properties with increasing frequency in different mixtures. Both G' (storage modulus) and G" (loss modulus) were increased with the increasing frequency, but tan $\delta$ decreased. As $\tan \delta$ was the ratio of G' and G', it reflected frequency affected G' more than G' and it also explained doughs had elastic fluid property. As for the mixture flour O1 (4\% oat, 5.5\%
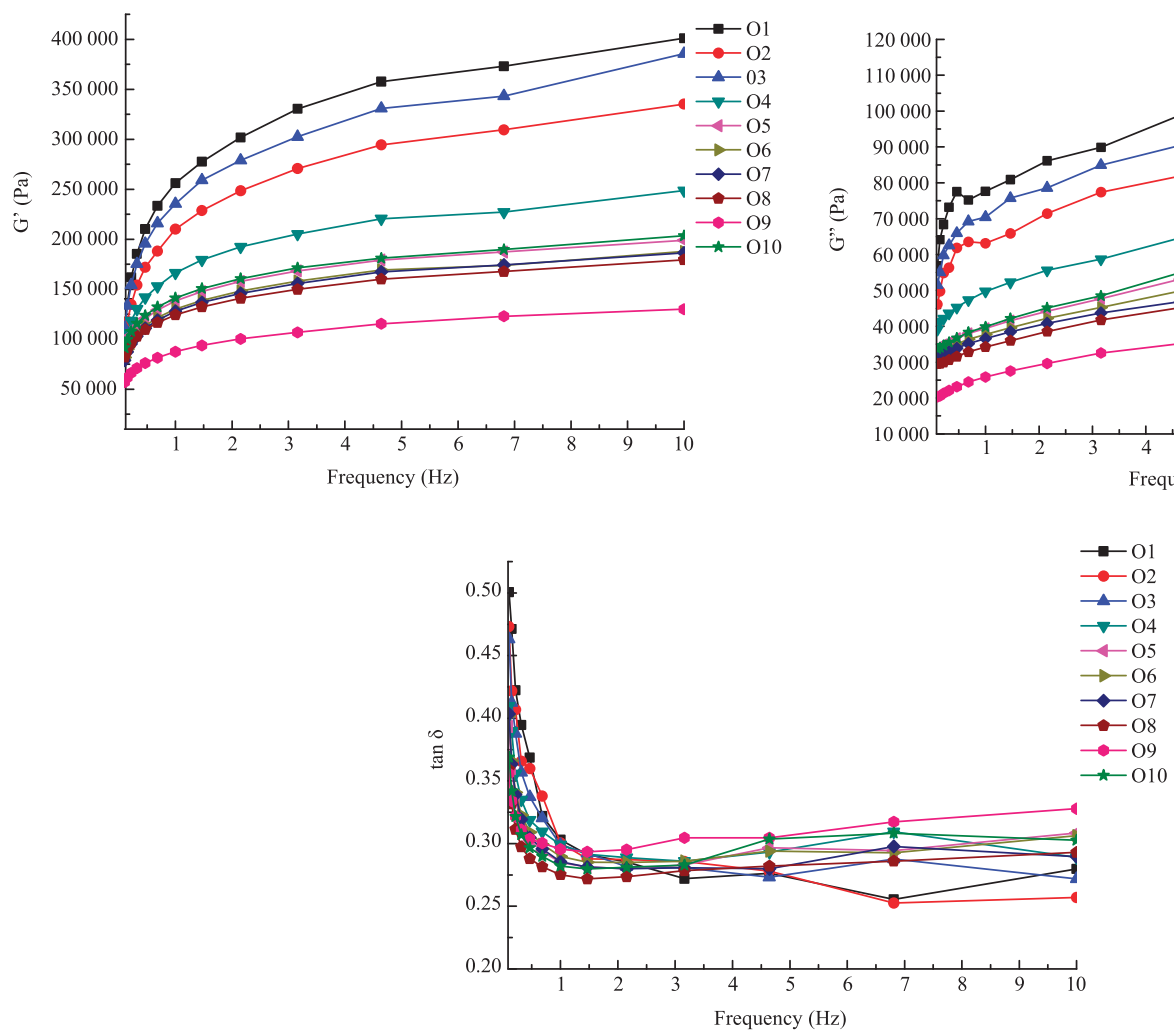

Fig. 2 Dynamic rheological properties of different multigrain doughs in the process of frequency sweep

\subsection{The Cooking Quality of Noodle Made from Different Formulas}

Mouth feeling was the main factor that affected multigrain noodles to be not as acceptable as the wheat noodles by most consumers. The sensory qualities and cooking characteristics of these 10 multigrain noodles formulas were studied. In general, noodles with lower cooking loss and higher water absorption were defined as good qualities noodles ${ }^{[29]}$. As showed in Fig. 3, the addition of millet flour improved a lot on sensory qualities, but the addition of soybean flour showed on the contrary way. As doughs' viscosity contributed the main structure of noodles. That might due to the lower viscosity provided by gelatinization of soybean (Fig. 1), the addition of soybean flour could not help the noodles forming better structures, thus it could not provide the resilience for the noodles. The viscosity provided noodles to have a tight structure, during the cooking time, it could contribute decreasing the loss. As shown in Table 4, O1

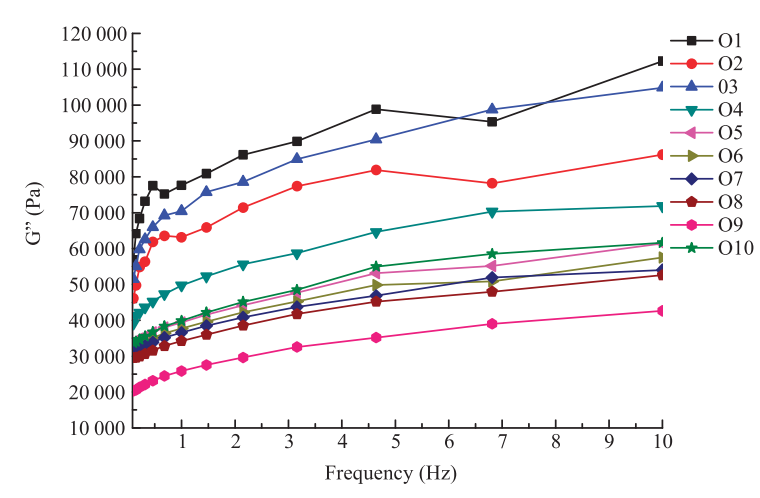

soybean, 5.5\% millet), its doughs had the highest G' and G'. Then following with $\mathrm{O} 3, \mathrm{O} 2$, and $\mathrm{O} 4$. Doughs with higher protein content had higher G' and G' values, different ingredients in flour such their dynamic and viscoelastic properties ${ }^{[26-27]}$. And their dynamic and viscoelastic properties were also closely related to the ratio of amylose with amylopectin, the structures of starch molecules, water content and the flour varieties. Fiber and gluten proteins both had strong water absorption, during the doughs forming, a part of water fiber as elastic filler was filled in doughs ${ }^{[28]}$. as proteins, fat, fiber and polysaccharide gave complex changes to was combined with fiber to reduce lubrication, at the same time,

had the lowest cooking loss, and O1 had the highest G' and G" values, that might contribute the viscoelasticity to resistant the loss of objects during cooking. As for the sensory quality, $\mathrm{O} 8$ had the highest value and with a higher viscosity peak, but it also had lower viscosity at the end. The reason might be higher final viscosity could yield more sticky noodles, and that influenced the mouth feel and surface condition of noodles. Additionally, $\mathrm{O} 1, \mathrm{O} 2, \mathrm{O} 7, \mathrm{O} 9$, and $\mathrm{O} 10$ had a good quality of sensory and lower final viscosity as well. To optimize sensory qualities, a regression equation was gained:

$$
\begin{gathered}
y=4.52142 * A+4.47449 * B+5.41785 * C-0.046893 * A * B \\
-0.084647 * A * C-0.25053 * B * C+0.039696 * A * B * C
\end{gathered}
$$

The quality of noodles was hardly defined by single index, by consider the gelatinization, rheological characteristics and cooking qualities of multigrain noodles with different formulas, the best proportion was obtained: $45 \%$ corn flour, $40 \%$ wheat flour, $4 \%$ oat flour, $11 \%$ millet flour. 
Table 4 Cooking qualities of noodles made with different mixtures

\begin{tabular}{cccc}
\hline Samples & Sensory quality & $\begin{array}{c}\text { Absorption rate } \\
\text { of dry matter }(\%)\end{array}$ & Cooking loss $(\%)$ \\
\hline O1 & $67.75 \pm 0.32^{\text {bcd }}$ & $163.79 \pm 0.41^{\mathrm{b}}$ & $0.72 \pm 0.01^{\mathrm{d}}$ \\
O2 & $69.25 \pm 0.25^{\mathrm{b}}$ & $198.93 \pm 1.67^{\mathrm{a}}$ & $1.01 \pm 0.02^{\mathrm{b}}$ \\
O3 & $64.00 \pm 0.61^{\mathrm{e}}$ & $165.69 \pm 0.16^{\mathrm{b}}$ & $0.92 \pm 0.03^{\mathrm{bc}}$ \\
O4 & $66.95 \pm 1.04^{\mathrm{bcd}}$ & $143.92 \pm 0.34^{\mathrm{d}}$ & $0.97 \pm 0.02^{\mathrm{b}}$ \\
O5 & $65.88 \pm 0.94^{\mathrm{cde}}$ & $149.13 \pm 0.66^{\mathrm{d}}$ & $0.85 \pm 0.02^{\mathrm{c}}$ \\
O6 & $64.88 \pm 0.63^{\mathrm{de}}$ & $164.28 \pm 0.83^{\mathrm{b}}$ & $1.02 \pm 0.02^{\mathrm{b}}$ \\
O7 & $68.13 \pm 0.83^{\mathrm{bc}}$ & $157.43 \pm 2.06^{\mathrm{c}}$ & $0.86 \pm 0.00^{\mathrm{c}}$ \\
O8 & $74.25 \pm 1.96^{\mathrm{a}}$ & $155.03 \pm 1.37^{\mathrm{c}}$ & $1.16 \pm 0.03^{\mathrm{a}}$ \\
O9 & $67.75 \pm 0.75^{\mathrm{bcd}}$ & $149.23 \pm 1.64^{\mathrm{d}}$ & $0.81 \pm 0.02^{\mathrm{cd}}$ \\
O10 & $69.88 \pm 0.77^{\mathrm{b}}$ & $146.70 \pm 0.35^{\mathrm{d}}$ & $1.01 \pm 0.00^{\mathrm{b}}$ \\
\hline
\end{tabular}

Note: Different letters in each column show statistically significant differences $(P<0.05)$ in different mixtures.

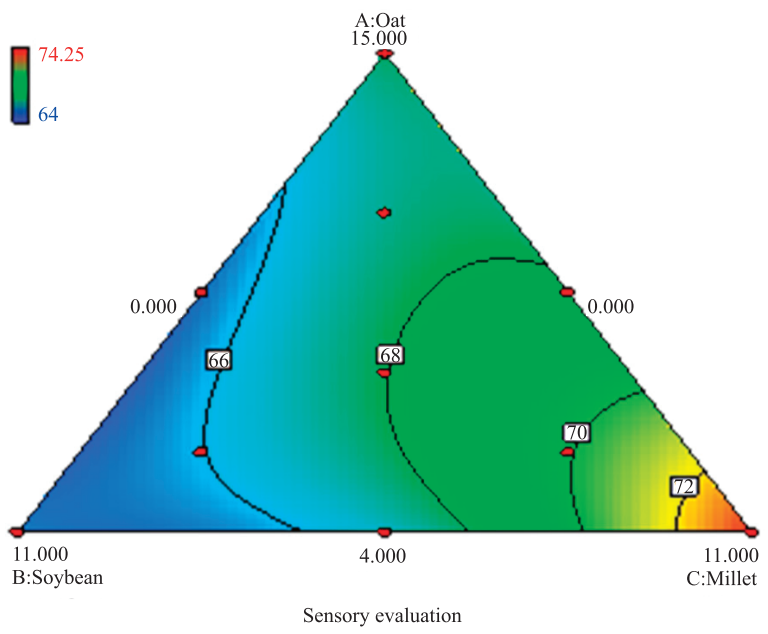

Fig. 3 Model graph of sensory evaluation of cooked noodles made with different mixtures

\subsection{Nutritional Components of Multigrain Noodles}

The nutritional components of multigrain noodles and wheat flour noodles were analyzed and showed in Fig. 4. Whatever in multigrain noodles or wheat flour noodles, starch was the main component. Actually, multigrain noodles had higher total starch (TS) content than wheat flour noodles. The reason might be that in multigrain noodles, corn flour occupied $45 \%$ and corn flour had higher starch content than wheat flour ${ }^{[30]}$. As Fig. 4 showed, almost all tested components of wheat flour noodles were lower than multigrain noodles, but except protein content.This is because wheat contains gluten, while other grains do not. Corn had enough dietary fiber which could resistant fat absorption ${ }^{[31]}$. Many researches had approved that reasonable dietary fiber intake could reduce the risks of coronary heart disease, stroke, high blood pressure, obesity and some gastrointestinal diseases. Apart from the dietary fiber, resistant starch (RS) also had positive effects for human body ${ }^{[32]}$. Resistant starch was a kind of starch or starch degradation products, which always be fermented by colonic microflora and could be digested in large intestine but escape in small intestine ${ }^{[32]}$. Therefore, resistant starch worked as fiber's functions. Food with enough resistant starch reduced more glycemic and increase SCFAs. SCFAs could make body feel satiety and help to control weight, that could be suitable for current healthy theory. Moreover, resistant starch could survive independent of intestinal flora, that helped to improve insulin sensitivity ${ }^{[33-34]}$. Thus, consuming high resistant starch content food was benefit for diabetes and obesity people.

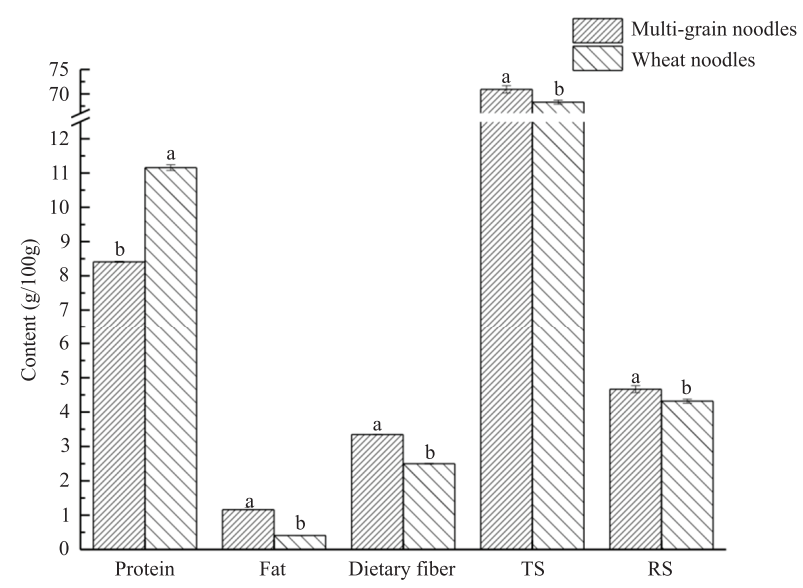

Fig. 4 Nutritional component of multigrain noodles and wheat flour noodles (cooked)

Note: Error bars indicate the standard deviation of replicates. Different letters above the histogram bars show statistically significant differences $(P<0.05)$ in different kind of noodles.

\section{Conclusions}

Multigrain foods or whole grain foods have more comprehensive nutrients than refined wheat flour products, and they are more suitable for human nutritional requirements. As wheat gluten is reduced in multigrain noodles, extrusion can be a viable method for noodle processing. Pasting and viscosities properties of multigrain flour were important for noodle processing. As showed by this study, soybean flour had negative effects on viscosity of the mixed flour and sensory qualities of the noodles, but oat flour increased the viscosity of the mixtures. The addition of millet flour could improve sensory qualities of the multigrain noodles. A proper multigrain noodle formula was obtained by comprehensive evaluation of doughs and noodles properties. The optimized multigrain noodles were richer in resistant starch and dietary fiber than wheat noodles. They are more suitable for people who wants to take a healthy dietary mode.

\section{Conflict of Interest}

The authors declare that there is no conflict of interest.

\section{References}

[1] NIU M, HOU G G, KINDELSPIRE J, et al. Microstructural, textural, and sensory properties of whole-wheat noodles modified by enzymes and emulsifiers[J]. Food Chemistry, 2017, 223: $16-24$.

[2] ZHANG N, XIU L, MIN W H, et al. The nutrition compound and valuation of the whole nutrition of maize[J]. Food Industry, 2014, 35(6): 98-101.

[3] AHN Y, PARK S, KWACK H, et al. Rice-eating pattern and the risk of metabolic syndrome especially waist; circumference in Korean Genome and Epidemiology Study (KoGES) $[\mathrm{J}]$. BMC Public Health, 2013, 13(1): 61-61.

[4] ANDERSON J W. Whole grains protect against atherosclerotic cardiovascular disease[J]. Proceedings of the Nutrition Society, 2003, 62(1): 135-42. 
[5] LIN B. Study on multi-cereal mixed flour of steamed bread[D]. Wuxi: Jiangnan University, 2008.

[6] PARRA C D L, SALDIVAR S O S, LIU R H. Effect of processing on the phytochemical profiles and antioxidant activity of corn for production of masa, tortillas, and tortilla chips[J]. Journal of Agricultural \& Food Chemistry, 2007, 55(10): 4177-4183.

[7] MA D Y, ZHANG J, LOU X Y, et al. Color, cooking properties and texture of yellow alkaline noodles enriched with millet and corn flour[J]. BMC Public Health, 2014, 13(1): 316.

[8] BEGHIN I, DE MELLO A V, COSTA T, et al. Assessment of biological value of a new corn-soy-wheat noodles through recuperation of Brazilian malnourished children[J]. American Journal of Clinical Nutrition, 1973, 26(3): 246.

[9] LIAO M Y, SHEN Y C, CHIU H F, et al. Down-regulation of partial substitution for staple food by oat noodles on blood lipid levels: A randomized, double-blind, clinical trial[J]. Journal of Food and Drug Analysis, 2018, doi:10.1016/j.jfda.2018.04.001.

[10] ADEPEHIN J O, ENUJIUGHA V N, BADEJO A A, et al. Bacterial ecology and rheological parameters of multigrain gluten-free sourdoughs[J]. LWT - Food Science and Technology, 2018, 96: 344-349.

[11] INDRANI D, SWETHA P, SOUMYA C, et al. Effect of multigrains on rheological, microstructural and quality characteristics of north Indian parotta - An Indian flat bread[J]. LWT - Food Science and Technology, 2011, 44(3): 719-724.

[12] AACC 76-21-1999. General pasting method for wheat or rye flour or starch using the rapid visco analyser[S].

[13] MARCOA C, ROSELL C M. Effect of different protein isolates and transglutaminase on rice flour properties[J]. Journal of Food Engineering, 2008, 84(1): 132-139.

[14] ROSA-SIBAKOV N, HEINIÖ R L, CASSAN D, et al. Effect of bioprocessing and fractionation on the structural, textural and sensory properties of gluten-free faba bean pasta[J]. LWT - Food Science and Technology, 2016, 67: 27-36.

[15] AACC 46-11A-1999. Crude protein-Improved kjeldahl method, copper catalyst modification[S].

[16] AOAC 985.29-1986. Total dietary fiber in foods enzymatic-gravimetric method[S].

[17] GB/T 5009.9-2008. Determination of starch in foods[S].

[18] ZHAO K, XUE P, GU G. Study on Determination of Reducing Sugar Content Using 3,5-Dinitrosalicylic Acid Method[J]. Food Science, 2008(8): 534-536.

[19] AOAC 2002.02-2002. Resistant starch in starch and plant materials enzymatic digestion[S].
[20] WANG N, MAXIMIUK L, TOEWS R. Pea starch noodles: Effect of processing variables on characteristics and optimisation of twin-screw extrusion process[J]. Food Chemistry, 2012, 133(3): 742-753.

[21] WU F, MENG Y, YANG N, et al. Effects of mung bean starch on quality of rice noodles made by direct dry flour extrusion $[\mathrm{J}]$. LWT - Food Science and Technology, 2015, 63(2): 1199-1205.

[22] WANG J. Study on the effect of oat or buckwheat flour on properties of mixed dough and quality of Chinese[D]. Wuxi: Jiangnan University, 2016.

[23] LI J. Study on flour properties and noodles qualities by adding soybean flour[D]. Wuxi: Jiangnan University, 2009.

[24] ZHAO X. Extrusion Characteristics of Foxtail Millet[D]. Yangling: Northwest A\&F University, 2006.

[25] WANG F, HUANG W, KIM Y, et al. Effects of transglutaminase on the rheological and noodles-making characteristics of oat dough containing vital wheat gluten or egg albumin[J]. Journal of Cereal Science, 2011, 54(1): 53-59.

[26] LI J, HOU G G, CHEN Z, et al. Studying the effects of whole-wheat flour on the rheological properties and the quality attributes of whole-wheat saltine cracker using SRC, alveograph, rheometer, and NMR technique[J]. LWT - Food Science and Technology, 2014, 55(1): 43-50.

[27] LI J. Implement of baking qualities of whole wheat saltine crackers and determination of the mechanism of water migration[D]. Wuxi: Jiangnan University, 2013.

[28] UTHAYAKUMARAN S, NEWBERRY M, PHAN-THIEN N, et al. Small and large strain rheology of wheat gluten[J]. Rheologica Acta, 2002, 41(1-2): 162-172.

[29] LOUBES M A, FLORES S K, TOLABA M P. Effect of formulation on rice noodles quality: Selection of functional ingredients and optimization by mixture design[J]. LWT - Food Science and Technology, 2016, 69: 280-286.

[30] LI H T. Study on the ruminal degradabilities of different wheat and maize varieties[D]. Jinan: Shandong Agricultural University, 2016.

[31] HUANG H, ZOU Y, CHI H. Quantitative assessment of the effects of chitosan intervention on blood pressure control [J]. Drug Design Development \& Therapy, 2018, 12: 67-75.

[32] ANDERSON J W, BAIRD P, JR D R, et al. Health benefits of dietary fiber [J]. Nutrition Reviews, 2010, 67(4): 188-205.

[33] LOCKYER S, NUGENT A P. Health effects of resistant starch [J]. Nutrition Bulletin, 2017, 42(1): 10-41.

[34] BINDELS L B, MUNOZ R R S, GOMESNETO J C, et al. Resistant starch can improve insulin sensitivity independently of the gut microbiota [J]. Microbiome, 2017, 5(1): 12. 